\title{
Is Trans-Korean Railway Solely a Symbol of Peace in the Korean Peninsula?
}

\author{
Minha Lee ${ }^{1}$ and Suh-Yong Chung ${ }^{2, *}$ \\ 1 Green School (Graduate School of Energy and Environment), Korea University, Seoul 02841, Korea; \\ minha_lee@korea.ac.kr \\ 2 Division of International Studies, Korea University, Seoul 02841, Korea \\ * Correspondence: mahlerchung@korea.ac.kr
}

Received: 23 October 2020; Accepted: 22 November 2020; Published: 24 November 2020

\begin{abstract}
The islandic geopolitical situation of South Korea led the road-centered development and the road freight share reached $97 \%$ in 2015. Trans-Korean Railway, thus, is the key to low carbon development of South Korea. With the Trans-Korean Railway, the export freights for Eurasia can be loaded at a local station for a direct rail transport instead of current d-touring road-ship intermodal transport. This will trigger domestic rail facilitation and reduce road externalities. The corresponding reduction of the shuttle shipment among South Korea-China-Russia may further contribute towards the environmental sustainability of the Yellow and East Seas. Yet, Trans-Korean Railway is considered as a symbol of "peace in Korean Peninsula" that there has not been a sufficient research on the environmental, social, and economic impacts of the Trans-Korean Railway connection. This paper, accounting on various phenomenal evidence including air pollution (environmental), public health risks and high fatality (social) and logistics inefficiency (economic), argues for the needs to change the discussion perspective on the Trans-Korean Railway from traditional politics to its environmental, social, and economic values.
\end{abstract}

Keywords: Trans-Korean Railway; road externality; phenomenal evidence; freight transport; low carbon development; South Korea; Eurasia

\section{Introduction}

The road dominated freight transport in Republic of Korea (South Korea: hereafter, ROK) since 1980 as the development of railways has been hindered by the islandic geopolitical situation. Being confined in a relatively small territory (world 107th) surrounded by three seas and Democratic People's Republic of Korea (North Korea: hereafter, DPRK), the investment for national infrastructure prioritized road adhering the 200 miles threshold of the railway service. (The 200 miles rail-truck economic breakeven point, claimed by the 1972 National Transportation Report of the US, became the global principal criterion and supported road-first policy decisions. The recent White Paper from the EC (2011) still conformed to this principle and set climate mitigation goals in freight to shift $30 \%$ of road freight transport over $300 \mathrm{~km}$ to rail or waterborne transport by 2030 and more than $50 \%$ by 2050). As the rail freight mode share in ton- $\mathrm{km}$ dropped below $5 \%$, lower than real island nations like Japan $(5.2 \%)$ and the United Kingdom (9.1\%) in 2015 [1], ROK joined the 15 world largest transport emitters, who collectively contributed $60 \%$ of the global transport emissions in 2017 [2]. More visibly, the air quality exacerbated since 2000 with increased particulate matter (fine dust: hereafter, PM) concentration as warned by a number of research [3,4].

This phenomenon contradicts the global trends towards sustainable transport for low-carbon development. Railway, which ROK has long neglected, is recognized as the backbone of sustainability for its higher energy efficiency and environmental-friendliness [5-8]. It is one of the few sectors where 
a clear decoupling between energy consumption and activity density has been achieved. In particular, IEA and UIC (2015) reported that the rail passenger activity has grown by $130 \%$ and freight by $76 \%$ while the energy consumption decreased by around $50 \%$ for both passenger and freight over 1975 and 2011 [5]. Globally three-quarters of the rail passenger movement and half of the rail freight relies on electricity today that rail transport is ready to take advantage of the renewable energies whenever and wherever possible. The High-Level Advisory Group for the 2030 Agenda for Sustainable Development has explicitly indicated that sustainable transport with railway at the heart is an enabler for all 17 Sustainable Development Goals (SDGs; the 2030 Agenda for Sustainable Development, adopted by all United Nations Member States in 2015, provides a shared blueprint for peace and prosperity for people and the planet, now and into the future. At its heart are the 17 Sustainable Development Goals (SDGs), which are an urgent call for action by all countries-developed and developing-in a global partnership. These recognize that ending poverty and other deprivations must go hand-in-hand with strategies that improve health and education, reduce inequality and spur economic growth—all while tackling climate change and working to preserve our oceans and forests. The Partnership for Sustainable Low Carbon Transport (SloCaT) has further highlighted that sustainable transport is candidly captured in seven of the 17 SDGs and five specific targets.). The United Nations (UN) emphasized the potential of rail as a climate mitigation item in their ASI strategy for the sustainable transport system: "avoid" the need for transport trips; promote a "shift" towards more efficient travel modes and "improve" the efficiency of vehicles and fuels accounting. The technical improvement is important as there is possibility of transport emissions outpacing the projections and become a roadblock to avoiding irreversible climate change in the absence of further action. Now it is said that the accomplishment of the Paris Agreement depends on an enhanced vision of a low-carbon, climate-resilient transport system. The actions involved include structural changes on all levels: governance, technological solutions, business models and financing infrastructures, including internalization of external costs.

Accordingly, the only solution to address both the sustainable development and economic feasibility of railway in ROK is to establish a direct railway between Busan and Amsterdam through the Trans-Korean Railway (hereafter, TKR). The concept of TKR is not new: it was first discussed at the St. Petersburg International Euro-Asian Conference on Transport in 1998. Yet it was not until 2011 that TKR finally appeared in ROK's national development paper (Modified II Comprehensive Plan under the Framework Act on Low Carbon, Green Growth). The TKR discussed at the "South-North Korea Rail and Road Reconnection \& Modernization Project (2018)" were Figure 1: Gyeong-ui (west coast), Gyeong-won (west-east) and Donghae (east coast) [9]. The Gyeongui Line, comprised of the Pyungui Line (Pyungyang-Sinuiju) and the Pyungbu Line (Pyungyang-Gaeseong), joins the Southern line at the Dorasan Station. The Gyeongui Line connects Gaeseong, Gariwon, Pyungyang and Sinuiju to link to the Trans-China Railway (TCR) or Trans-Mongolia Railways (TMGRs). The Gyeong-won Line misses $28 \mathrm{~km}$ between Baekma-goji (ROK) and Pyunggang (DPRK) while Gyeong-ui Line is stopped politically. The Donghae Line, connecting Busan (ROK) to Rajin (DPRK) and Khasan (Russia) through Pyungra Line, currently misses $104 \mathrm{~km}$ between Gangreung and Jejin in ROK. The Donghae Line is considered as the best option to connect TKR to the Trans-Siberian Railway (TSR). 


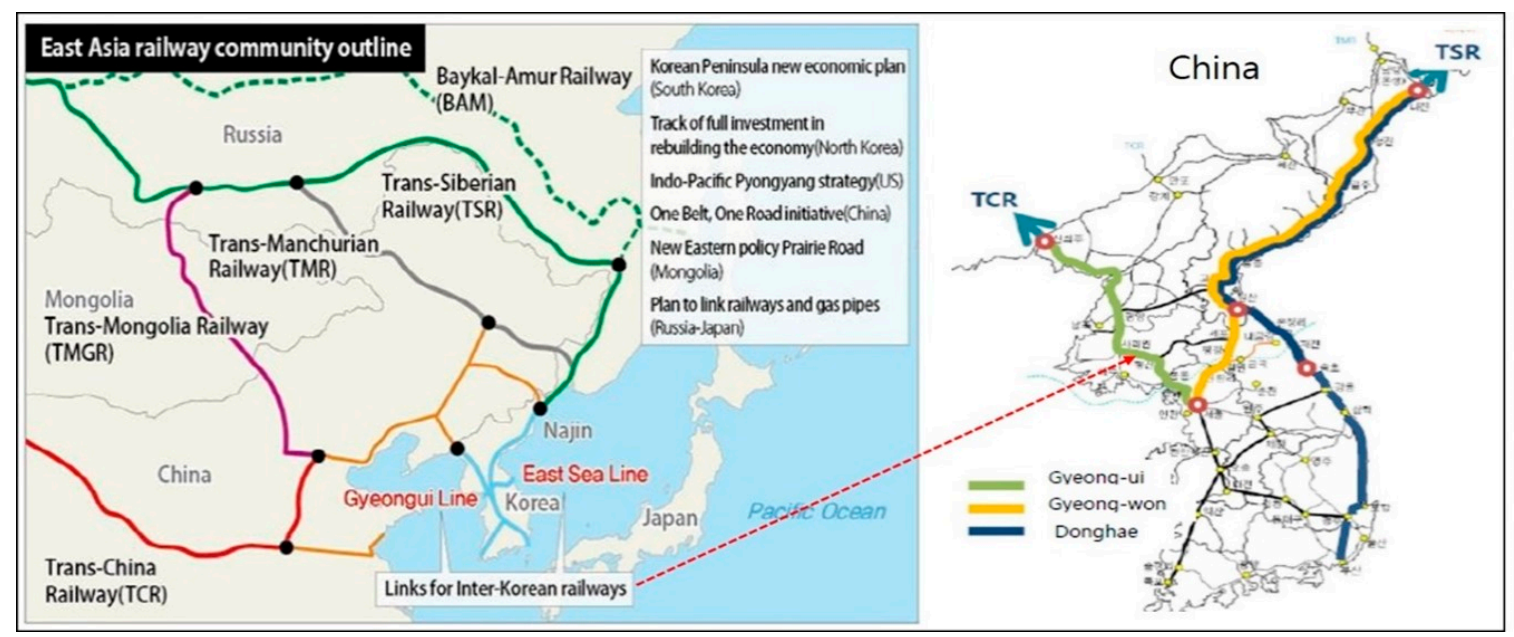

Figure 1. Map of the Trans-Korean Railway (TKR) connected to the trans-continental railway; source: the Korea Maritime Institute (KMI; 2018) p. 3 and 5, modified [10].

Historically, the primary approach of the Trans-Korean Railway (hereafter, TKR) has been limited to political perspectives. Since the first introduction at the Inter-Korean Summit Meeting in 2000, it was registered as a political agenda. The Eurasian Initiative, announced in 2013, also defined TKR within a broader concept of Silk Road Express as a mean "to move towards a single united continent, a continent of creativity and a continent of peace". The policy goal expanded only slightly to build regional peace and economic prosperity in 2018 with the proposal to launch East Asia Rail Community similar to European Coal and Steel Community [11]. Consequently, the research discipline has also been tilted heavily towards the political analysis on academic field and policy impact analysis, comprising either environmental or economic quantitative modeling, at the national research institutes like the Korea Maritime Institute (KMI) and the Korea Transport Institute (KOTI).

Furthermore, the most recent governmental study on the air quality management in urban areas through transport emission reduction (Report on the Transport Energy Re-pricing Policy Joint Research [12]) under the "Special Protocols to Manage Fine Dust" in 2016 exhibited the prevailing road-centered paradigm in the transport policy-making procedure in ROK. With no consideration on the possible rail facilitation through TKR connection, the environmental economic model developed in the research assumed no mode shift from road to lower carbon transportation. It adopted the "elasticity" as the measure to assess effectiveness of the transport energy pricing policy, the well-known necessity of the modern economy, and excluded $12 \%$ of freight trucks that are subject of the fuel subsidy law of ROK. Consequently, the research concluded the effects of diesel price increase on PM emission reduction will be minimal with large negative economic impact because the energy demand will remain unchanged despite the increased price.

All in all, the previous studies fall short of addressing the essentiality of TKR for ROK's low carbon development. This paper attempts to correct this misperception of TKR: TKR connection is not a political item or a good economic opportunity that ROK can live without. Instead, this paper presents an argument for why the central role of TKR connection should be the rail facilitation to reduce the environmental, social, and economic externalities of over-flourishing road freights in ROK. Learning from the previous discussion failure due to the research results influenced by the road-centered paradigm, this paper for a successful implementation of sustainable transport policies. This paper, hence, elaborates on the phenomenal evidence of environmental, social, and economic potential of TKR connection rather than undergoing a model analysis, of which results depends heavily on the governing paradigm under the name of "model assumptions". Instead, the paper aims to initiate a new strand of discussion on the sustainability of ROK's freight transport system with a road-rail balanced viewpoint. 
The research focus is on the freight transport because of two reasons. First, the improvement of the freight transport mode share between road and rail in ROK is more system effective than the passenger in accomplishing the goal of sustainable transport. The freight transport is also easier to regulate than that of passengers as it involves less interested parties with more defined preferences, which may serve as a good starting point with that extra security to a politically sensitive item like TKR. For these aims, the paper is constituted of three main sessions. In the following session, the previous studies on the sustainable transport and TKR have been reviewed. It is further elaborated on how it is timely and critical to review the TKR connection in the perspectives of the sustainable transport and low carbon development. The associated geopolitical issues accounting for socioeconomic situations ROK is currently in are neglected intentionally. In Chapter 3, the paper focuses on the current transport system of ROK. The analysis on both domestic and international freight trade routes shed lights on the total exclusion of rail development in the freight transport system of ROK. In the last chapter leading to conclusion, the paper elaborates on the phenomenal evidence of three major types of externalities: air quality (environmental), public health and fatality (social) and logistics efficiency (economic).

\section{Literature Review}

Since the transport emission was recognized as one of the major impediment to sustainable development, many efforts were exerted to specify various externalities from which a shift to demand management (predict-and-prevent) away from traditional road centered development (predict-and-provide) occurred in 1995 [8]. The liability of the transport sector increased further in recent years, as it became the last remaining source to grow while others demonstrate emission reduction through emission control measures and related technology advancement. There still is a lingering belief that diverting away from trucks may be neither easy to achieve nor significantly effective in addressing these externalities [13]. Yet there also is a growing consensus that well balanced use of road and rail is one of effective climate change mitigation policy. In particular, the latest EU White Paper on Transport (2011), while still adhering to the 200 miles threshold, set climate mitigation goals in freight to shift $30 \%$ of road freight transport over $300 \mathrm{~km}$ to rail or waterborne transport by 2030 and more than $50 \%$ by 2050 . A basic tool for meeting this target is the green corridors (green corridors aim at improving the competitiveness of rail and waterborne transport, which, in turn, would enable exploitation of the superior GHG-emission characteristics of these modes in comparison to the road), a European concept denoting a concentration of freight traffic between major hubs and by relatively long distances. The effectiveness of this rail facilitation has been statistically supported by the case analysis in Denmark where positive impacts were observed in the indicators examined (cost, speed and transport emissions) [14].

The three types commonly considered as external costs in the transport sector are: (1) the environmental impact in terms of short-range (noise, air pollution and aesthetic impact) and long-range pollution (GHGs, black carbon and particular matter emissions), (2) social impact represented by accidents (fatality and injuries) and air pollution related diseases (pain and suffering) and (3) economic effects of congestion. The first environmental category is rather straight forward as the numbers from the technical factsheet alone tell that road activity is 11 times more energy intensive than railways [11,12]. The higher risks of road accidents than the railway system is another uncomplicated interpretation of statistics. Many studies also verified that the road emission in urban areas is more critical to public health, visibility and plant growth than a chimney in the industrial areas [3] being much closer to human receptors [15]. The economic downside of road transport had long been underestimated due to the firm belief that road is the most efficient and convenient mode to move. As the related studies advanced, however, understanding of traffic congestion expanded to a wider range of negative impacts beyond time delay to additional pollutant emissions (environmental) and business inefficiency (economic) [16]. It has been found that road congestion degrades business productivity by reducing logistics efficiency. While one strand seeks to flatten the traffic volume throughout the day by enhancing road logistics system or shifting freight travels to off-peak hours 
(through congestion charge, subsidies and other measures), the other focused on the potential of rail freight. The second group argue that mode shift towards rail freight is the only meaningful solution as off-peak hour freight movement inherit higher risks by nature (e.g., accidents and noise) while it fails to address the fundamental problem of pollutant emission and traffic volume [17]. In combination, the research emphasizes the importance to decouple economic activities (development) from transport emission by increasing shares of transport modes that is safer, more environmental-friendly and congestion-free: namely, rail and waterborne transport. There now is a growing consensus that a significant carbon reduction in the transport sector is a prerequisite to a greener transport network building as transport infrastructure related decisions "lock-in" transport demand for decades to come $[12,18,19]$.

Yet, the political perspective still dominates the discussion on the TKR that the research keywords usually include "unification", "peace" and "inter-Korean cooperation" [20,21]. The "opening and economic development of DPRK through TKR as a supportive infrastructure" frame [22] of political economy papers is not only a biased evaluation but also a largest obstacle to further progress of TKR (UN sanctions). Even the economic model analyses assume unified Korea, or at least cooperative partnership, and evaluate the economic potential of TKR mainly as inter-Korean movement [23,24]. Although economic analyses on TKR as an efficient overland trade route between ROK and Eurasia appeared recently, the studies are more of a feasibility test on inter-Korea infrastructure $[1,25]$ than academic research on economic impacts of rail facilitation in ROK. More broadly, there is hardly any study on environmental and social impacts of TKR in ROK being confined in the islandic geopolitical frame. Likewise, there has yet been any research on TKR from the pure railway perspective without considering its physical location being across the two Koreas. For this matter, there are not many academic research papers on TKR aside of policy discussion papers issued by governmental research institutes.

These trends of previous studies well demonstrate how the political aspect has dominated the whole discussion procedure of TKR and how the islandic geopolitical situation has encroached on the transport system development in ROK. It is time to correct this partiality as the consequent restrictions on rail facilitation pose serious risks to low carbon development of ROK at the least, if not the global sustainable development.

\section{Current Freight Transport System in ROK}

The total rail extension in 1945 was reported as $6326 \mathrm{~km}$ (752 stations) throughout the Peninsula and was connected to the Eurasian continent that people and goods went to Europe on rail. Unfortunately, the connectivity terminated over the Korean War and ROK is now left with the air and seaway routes to the Eurasia continent and the world. The entangled political issues and the ideological confrontations confined design of land transport to ROK's territory: the progress of transport infrastructure building between the two Koreas, including TKR, proceeds with the "strong political will" and currently is on halt. Under this unique situation tied with a traditional 200 miles threshold, only 16 tug lines have been installed nationwide: nine international ports of Busan and Busan New Port, Gwangyang, Masan, Mokpo, Ulsan, Mookho, Yaosu, Incheon and Changhang; and seven industrial complexes of POSCO, Gwangyang Steels, Daebul National IC, Yaosu National IC, Ulsan and Onsan Ordinary IC, Cheonju First Ordinary IC and Changwon National IC. Consequently, the rail freight share dropped below $2 \%$ in 2015 from more than $50 \%$ in the 1960 s and $28.4 \%$ in 1980 (Table 1). 
Table 1. Freight modal split in Republic of Korea (ROK) in 2015.

\begin{tabular}{cccccc}
\hline & Rail & Road & Marine & Air & Total \\
\hline Freight 1000 Ton & 37,094 & $1,761,291$ & 128,611 & 288 & $1,927,284$ \\
(Mode Share, \%) & $(1.9 \%)$ & $(91.4 \%)$ & $(6.7 \%)$ & $(0.0 \%)$ & $(100 \%)$ \\
\hline Freight (1M Ton-km) & 9479 & 132,382 & 31,841 & 112 & 173,814 \\
(Mode Share, \%) & $(5.5 \%)$ & $(76.2 \%)$ & $(18.3 \%)$ & $(0.1 \%)$ & $(100 \%)$ \\
\hline \multicolumn{5}{c}{ Source: MOLIT [26]. }
\end{tabular}

\subsection{Domestic Freight Transport Route}

KOTI outlined the domestic freight logistics in three phases: production site (e.g., individual factories and industrial complexes, IC), interchanging centers (e.g., intermodal freight centers and logistics complexes) and consumption sites (e.g., major outlets and export channels such as ports and airports). The products from the ICs, once ready for delivery, are typically gathered in nearby inland logistics depots, which constitute an inland container depot (ICD) for international trade and integrated freight terminal (IFT) for domestic freight deliveries. The inland logistics depots in ROK lack transport connectivity (no railway extension) and comprise only of assembly and wrapping lines and storages [27]. Furthermore, ROK logistics network is covered mainly by individual small firms that it is deficient of a systematic network connecting production site to either the trading spots (airports and ports) or the final consumption sites. ROK has also been ranked 24th on the World Bank's National Logistics Competitiveness assessed by six indices including cost and infrastructure (As the logistics industry is considered as a supporting service for the main production chains (rather than an independent industrial sector), the total sales volume of the largest logistics company in ROK (Hyundai Glovis) amounts to only $40 \%$ of the global industry leader (DHL Supply Chain and Global Forwarding). The statistics record listed total of 129,103 freight trucks travelled in and out of ICs every day, forming $30 \%$ of the daily traffic in and out of ICs [28]. The highest truck traffic was reported from Ulsan Modulization IC (58\%), Choongnam Daejuk IC (60\%) and Jeju Seoguipo-daejung Agricultural IC (53\%). As for the inland logistics depots, total 78,477 freight trucks ( $60 \%$ that goes to ICs) delivered goods per day. In terms of types of the logistics depot, the share of truck entry was higher at the IFT $(63.7 \%)$ than the ICD (56.8\%) [28].

Either collected at the inland logistics depots or sent directly, the goods for exports are separated from domestic goods for destined trading spot, namely Incheon International Airport $83.1 \%$ of total air freight in 2018; 4th in the world) and Port of Busan (75.5\% of total international container freight in 2018; 6th world largest port) [29]. Approximately $68 \%$ of the direct import and export trade volume is domestically transported to the Port of Busan. The largest portion (23.9\%) comes from Seoul, followed by Kyungnam (19.8\%) and Kyonggi (15.8\%) [30]. On the other hand, 72.8\% of direct import and export processed at the Incheon International Airport are domestically transported. The largest origins and destinations for the air freight to Incheon International Airport are also Kyonggi (34.2\%) and Seoul (29.7\%) [31]. Despite the long distance between Seoul and Port of Busan and the heavy weight of the goods (three major traded items at Port of Busan: chemical (39.7\%), machinery $(31.9 \%)$ and agricultural $(25.7 \%)), 93 \%$ comes on road with only $7 \%$ on rail and none on short-sea shipping since 2016 [26]. Furthermore, Incheon International Airport is not even rail connected for freights.

\subsection{International Freight Transport Route}

ROK is one of the largest exporting economies in the world. Following the new global economic restructuring with the global supply chain and the rise of the newly industrialized economies (NIEs), ROK's trade density shifted from markets in the West hemisphere to next supply chain sites in the east. As ROK's major companies established factories in Eurasian nations, the intraregional trade share increased significantly: Russia (export 21\%, import 16.4\%), Eastern Europe (11.6\%, 6.8\%), 
Commonwealth of Independent States (CIS; 20.3\%, 2.4\%) and Northern Europe (4.7\%, 14.4\%). China overtook the US as the largest trade partner of ROK since 2003 [1].

The three major trade routes between ROK and Eurasia currently are: (1) the intermodal route involving shipment between ROK (Incheon or Busan) and China (Liayungang or Qingdao) for a change to TCR to CIS countries and Central Europe through China and Mongolia, (2) an intermodal route involving shipment between ROK (Busan) and Russia (Vostochny or Vladivostok) to change to TSR for Northern and Western Europe through Russia and (3) a direct shipment from ROK to Middle East or Western Europe through Suez Canal. Before 2000, the marine route (3) dominated ROK-Europe trade that only $5 \%$ was on trans-continental railways [32]. The share of rail transport, however, increased recently. With the railway expansion down to Southwest Asia, TCR connects to several landlocked countries, namely Kazakhstan (Almaty), Uzbekistan (Asaka and Andijan) and Turkmenistan (Türkmenbaşy), where train freight holds definite competitiveness over marine shipping [1].

The deepening global supply chain between ROK and Eurasian countries boosted the shuttle shipment volume between ROK, China and Russia for intermodal transport via TCR and TSR, respectively: Hyundai ENG (Turkmenistan), Hyundai Construction (Uzbekistan), Samsung Electronics (Slovakia, Russia, Poland, Hungary), Hyundai and Kia Motors (China, Poland, Czech, Slovakia), LG Electronics (Kazakhstan, Russia, Poland), GM Daewoo (Uzbekistan) and SK Innovation (Hungary) [1]. Tied with the increased direct investment to Russia, ROK's major companies became favorable to TSR than the marine shipping, as the block train directly operate to factory plant areas: Taganrog (Hyundai's car-assembly plant), Izhevsk (Kia Motors assembly line), Naberezhenye Chelny (Ssang Yong Motors) and Ruza (LG Electronics) [23].

On the other hand, transit volume constitutes a significant share in freight movement around ROK. The highest transit share is reported from the freight movement between Port of Busan and Ports of China ( $61 \%$ of total trade volume by weight) with the highest growth rate of $4.3 \%$ reported between 2012 and 2017 [23]. One of the major attractiveness of the Busan Port as a transit site is the aggressive marketing efforts by major ROK logistics forwarders. The ROK forwarders took initiative opening new container block train routes such as Tianjin/Qingdao-Alashankou and Vostochny-Poland that they now enjoy bulk discounts on rail transport fees on both TCR and TSR. This discounted rate provides cost competitiveness to intermodal deliveries to Central Asia and Europe from Busan on TCR/TSR and maintains competitiveness of Busan Port as the transit site [24].

As illustrated, both the domestic and international freight transport volume of ROK is heavily concentrated in a few key spots: Seoul/Kkyonggi, Kyungnam, Busan and Incheon. Although the main railways are established in all these provinces, over $90 \%$ of the freight volume is moved on the road (domestic) and seaway (international), as the access to the actual freight originating and destined spot is limited to the trucks rather than the trains. The reconfiguration of this freight movement is an urgent policy agenda as the consequent externalities heavy road use became phenomenally evident in the recent years, concurring with the findings of previous studies: air pollution and climate change (environmental), public health exacerbation (social) and logistics inefficiency (economic).

\section{Phenomenal Evidence of the Road Freight Externalities and Need for Rail Facilitation}

\subsection{Environmental Phenomenal Evidence}

The domestic freight movement pattern of ROK is highly damaging on environment perspectives. The local pollution that the freight trucks in ROK has been reported to consume 2.6 times more energy per ton and emits 10 times more air pollutants per ton- $\mathrm{km}$ than the diesel rail trains [33]. As the production sites are located around Seoul/Kkyonggi regions and the major consumption happens at the Port of Busan, at least 3 million TEU is transported on Kyungbu Highway annually. The environmental damage caused is greater than the reported freight transport as the average empty return ratio is $40 \%$ [34]. The emission reduction may have reached 16 million tons from a total of 105 million tons if the rail freight share has been increased to $18.5 \%$ by 2020 from $8.1 \%$ in 2008 as the Ministry 
of Land, Infrastructure and Transport (MOLIT) had intended [27]; MOLIT had pursued the policy driven mode shift through the Modified II Comprehensive Plan in alignment with the "Framework Act on Low Carbon, Green Growth (2010)". The hard reality, however, was that the rail freight shares dropped to $1.6 \%$ in 2016 signaling a clear limitation to effectively implement the shift policy (from ASI strategy of the UN) in ROK even at the presidential policy level without the launch of the TKR connection. Incidentally, the air quality in ROK exacerbated noticeably since 2010 when the rail share fell below 5\%. The air pollution persisted at the average metropolitan PM concentration of 20-30 $\mu \mathrm{g} / \mathrm{m}^{3}$ (with the number of days classified as "bad air quality" ranging between 60 and90 annually) in 2016-2019 [35] and the Government effectuated "Special Act on Fine Dust Reduction and Management" in 2019. The "Governmental Report on the Transport Energy Re-pricing Policy Joint Research [12]", without consideration on rail use, estimated the environmental damage to have amounted to 6.7 trillion KRW, 20 trillion KRW and 1.6 trillion KRW for petrol, diesel and LPG, respectively (Table 2). In spite of the aforementioned generous approach being governed by the road-centered paradigm, the heavy diesel engines were found to contribute $46 \%$ (13 trillion KRW) of the total environmental costs, among which the fine dust emission damage marked 11 trillion KRW by emitting $65 \%$ of the total PM as the primary emission source. The Organization for Economic Cooperation and Development (OECD) in 2016 also placed ROK at the top of the countries to be most affected by the exacerbating air pollution, including the fine dust, in their research titled "Economic Consequence of Outdoor Air Pollution".

Table 2. Environmental cost by air pollutants (in hundred million KRW).

\begin{tabular}{ccccccccc}
\hline \multirow{4}{*}{ Petrol } & CO & NOx & SOx & VOC & PM2.5 & CO $_{2}$ & Total \\
\hline \multirow{5}{*}{ Diesel } & Passenger & 34,076 & 9203 & 20 & 494 & 64 & 6961 & 50,817 \\
& Van & 13 & 5 & 0 & 0 & 0 & 1 & 19 \\
& Heavy & 25 & 6 & 0 & 0 & 0 & 4 & 35 \\
& Motorcycle & 14,467 & 1342 & 3 & 120 & 0 & 464 & 16,396 \\
\hline \multirow{4}{*}{ LPG } & Passenger & 3422 & 36,278 & 9 & 63 & 5515 & 4619 & 49,906 \\
& Van & 2170 & 17,015 & 5 & 32 & 1237 & 1411 & 21,870 \\
& Heavy & 13,114 & 94,611 & 26 & 321 & 12,396 & 7865 & 128,223 \\
\hline \multirow{2}{*}{ TOTAL Heavy } & Passenger & 8194 & 2804 & 6 & 29 & 0 & 3132 & 14,165 \\
& Van & 335 & 59 & 0 & 1 & 0 & 54 & 450 \\
& Heavy & 970 & 263 & 0 & 4 & 0 & 172 & 1409 \\
\hline
\end{tabular}

Source: Final Report p. 28 (modified) [12].

Regionally, a typical export item manufactured in the northern region (Seoul/Kkyonggi regions) is road transported down south (Busan) to be shipped north (China or Russia) again through the Yellow Sea or East Sea. This D-tour intraregional trade route results in the double or triple (if truck returns empty) excessive emissions. This environmental damage is avoidable if the export freights for Eurasia countries can be loaded at a local station for a direct rail transport, namely TKR. There is good evidence that TKR connection will relieve some burden off the Yellow Sea, which UNDP/GEF reported as one of the most polluted regional seas in the world being surrounded by China and two Koreas [36]: the trend observed in the Busan-Rajin container shipment in 2000-2010. Over the period, the freight volume doubled attracting goods from three Northeast Provinces of China (NE China: Liaoniang, Jilin and Heilongjiang) beyond ROK-DPRK trade. With the route closure over political strains in 2010, 550 thousands TEU, representing 11\% of total ROK-China trade processed at Busan Port, is now transported through shuttle shipping between Busan and Dalian [37,38]. Furthermore, because of the current seaway-only route to the Port of Busan, a large share of cargoes from China that are transit in Busan to Vostochny takes a U-trip around the Korean Peninsula (down the Yellow Sea and up across the East Sea) accumulating avoidable carbon emission around ROK [22]. Hence, a full mode shift to 
TKR will contribute significantly to the environmental enhancement and traffic control in the Yellow Sea and domestic pollution emission reduction.

\subsection{Social Phenomenal Evidence}

There are two types of social costs aroused with the road-centered freight transport in ROK. First is the life lost in the road use in the form of time (congestion) and injury/fatality (accidents). The degree of both congestion and accidents tend to become more serious when freight trucks are involved due to its larger size and weight. The traffic flattening policies to address congestion, through which a significant road freight volume has been diverted to off-peak hours, is malfunctioning in ROK: Korean Expressway Corporation reported that $75 \%$ of total highway fatal accidents involved freight trucks among which $44 \%$ occurred during the off-peak hours (10 pm-6 am) in 2018 [38]. Consequent to this high accident ratio, $53 \%$ of the total road fatality (1079 cases in 2018) included truck drivers. With this significant contribution from the freight transport, ROK reported a 1.6 times higher fatality rate than the average road death in a 100 thousands population in 2017 [39,40]. The two major causes of the road freight accidents are the incorrectly loaded goods and the drowsy driving as the delivery trip usually involves a long distance (average $113 \mathrm{~km} /$ day) at late hours (1-7 am [38]. The low load ratio and high empty return ratio also represent congestion caused by avoidable truck journeys on the road, which links to the third economic phenomenal evidence [41]. The congestion cost of the road use has been estimated to 60 trillion KRW, equivalent to $3.4 \%$ of the gross domestic product (GDP) increased by $6.6 \%$ from 2016 [39]. The freight vehicle constituted $27 \%$ to the total road use in 2014-2018 [42]. Furthermore, the high fatal accident ratio of road freight also contributes much to congestion as the accident accompany a minimum of a one-hour delay due to lane(s) closure for investigation and cleaning.

On the other hand, the air quality marked the "health hazardous" level in many urban cities of ROK in recent years. The high PM emission may not have caused public health risks without the reduced ventilation capacity of the region due to climate change. The Statistics on National Disease shows a clear increase in respiratory related patients with symptoms ranging from a mild cough to fever since 2010 [43]. Many studies found strong correlation between the PM concentration and admission of respiratory patients, especially in children and the elderly [44]. The impact is found to be greater the smaller the particulate as the ability to penetrate the lung comes with a smaller size (PM2.5 is more hazardous). The mode shift to rail from road will, subsequently, reduce the overall social cost of freight transport in ROK. The black carbon emission reduction from the freight transport will lower the respiratory health risk. The reduced long-distance freight transport volume between Seoul and Busan, following a mode shift to rail, will also lower the risks of drowsy driving and, thus, the consequent road accidents. In turn, the increased share of local delivery (local door-to-door and rail station freight processing) will offer better business model for small logistics firms, which constitute $20 \%$ of freight industry, where overall logistics efficiency will be improved [42].

\subsection{Economic Phenomenal Evidence}

There are two major logistics inefficiency arising from the islandic situation of ROK that are intertwined. The road-centered transport system development pursued under the "providing" transport policy enhanced road convenience that activated rebound effects in ROK. As seen in the results, road absorbed the growing freight volume that amounted to 1927 billion tons in 2015, a fivefold increase from 337 billion tons in 1990 [28]. In turn, small freight companies (market share $20 \%$ ) joined the flourishing road freight market and resulted in the first type of logistics inefficiency: high transportation costs. The domestic logistics processing (i.e., transport, inventory, wrapping and handling) is divided into different independent companies without the overarching system. This layered logistics prevent efficient packaging that the load ratio is lower (average 67\% contrast to $83 \%$ of the corporate one) and the empty return ratio is higher (average $44 \%$ contrast to $30 \%$ ) [25], causing additional congestion accumulating social costs of the road use. The transportation costs, thus, is 
accumulated inefficiently that the unit cost of the road (702 KRW/ton-km in 2016) is more than three times of that of air (207 KRW/ton-km) [42]. This is exceptionally high road freight costs globally and is incompetency for a trade-centered economy like ROK.

The rapidly growing rail freight share in Eurasia in comparison has caused the second type of logistics inefficiency: unnecessary U-touring around the Peninsula. While ROK is stumped with this U-trip, the other Eurasian countries advanced into direct rail freight particularly for the high-value electronic commodities. These freights owners halved the travel distance $(11,000 \mathrm{~km})$ from the traditional shipping via Suez Canal $(24,000 \mathrm{~km})$ and enhanced reliability being weather independent [45]. The major reason of the shipping route through Suez Canal still being the most popular trade route in ROK is the extra costs of mode change (train-ship) and paper works on the border crossing. In this light, with TKR connection, domestic freight owners can enjoy a shortened delivery time and cost reduction including improved liquidity [42]. Considering the capacity limitation on the trans-continental railways and the clear advantage of rails in accessing the landlocked countries, the potential is greater for goods destined to central Asia through TCR than those for Europe on TSR. The freights volume to these destinations is already counted in TCR capacity as it is currently transported through the intermodal delivery service connecting shipment from the Port of Busan to rail shift at Ports of Liayungang, Shanghai and Qingdao [45]. As the trade between ROK and the Central Asian countries demonstrate a strong increasing trend, a significant cost reduction is anticipated once a direct railway is established [39].

The last economic benefit is expected at the final rail stations, potentially Ports of Incheon and Busan, with additional freight processing competitiveness connecting to shipment outside the region as a logistics hub port. Accounting high transit share in both Ports of Incheon and Busan for the rail shift at Ports of Liayungang, Shanghai and Qingdao, the possibility to shift to intermodal for direct TKR connection to continent is high and ready According to the KITA Statistics, ROK's major export items are the intermediate parts and the final products of heavy and chemical industry (automotive and construction materials constituting $60 \%$ of total exports in 2016) and IT goods (26\%) while, the raw materials and capital goods contributed 79\% of total imports in 2016. The two Koreas may also benefit from rail levy and economic promotion of other related industries as path managers. Thus, an early development of the direct trade route among China, Japan and Russia, before the launch of TKR, may greatly affect the competitiveness of Port of Busan. In this light, equipping the Port of Busan with direct railway connected to trans-continental railways through the Donghae line is crucial for maintaining the advantage from other closely located ports in China and Japan.

\section{Conclusions}

Despite this essentiality of the TKR connection for low carbon development of ROK, the general perception of the "South-North Korea Rail and Road Reconnection \& Modernization Project" is an unnecessary infrastructure building that requires a large investment with a low expected rate of return called "unwarranted peace in Korean Peninsula". It is time to correct this prejudice and change the major perspective on TKR to its environmental, social and economic values (sustainability) away from political difficulties. The TKR connection should be properly evaluated for its genetic potential as rail transport between Busan and Amsterdam, with a particular emphasis on its possible role as a trigger to the domestic rail facilitation, for the low carbon development of ROK.

If needed, the physical location can be considered as TKR cuts across an empty land (TKR may not have any stops in DPRK) and simply connects ROK and China/Russia for TCR/TMGR and TSR, respectively. In this case, a large payment may be requested from DPRK for their land use, but it may easily be smaller than the total social costs ROK is paying in terms of exacerbating air quality and public health, time and economic opportunities lost on busy roads, degrading logistics competitiveness and many lives on fatal accidents. The risks against a reliable operation can also be managed with a strategic system. First, various safeguards to guarantee the operation of the train according to the promised schedule can be implemented. Secondly, the mode share among the available trade route between ROK 
and Eurasia (i.e., current road-seaway) should be maintained in a balanced manner for comprehensive growth. Once TKR is connected to TSR and TCR, the political instability becomes a regional issue, beyond DPRK, as evident in the recent TSR interruption over political conflicts in Central Asia [46]. Considering the close political and economic relations of DPRK with China and Russia, the risks DPRK must take to treat TKR as a political weapon may be higher than ROK anticipates. Three readily available safeguards are: (1) strategically organizing the train schedule to have only one block train travelling through one risky territory to minimize the loss at the worst case, (2) incorporation of the latest IT technology to track the freight closely as a service to the customer's logistics management and as antitheft procurements and, lastly, (3) enough economic incentives to the land lenders (i.e., DPRK for TKR) to protect the railway from political games. It is more likely for politically unstable governments to use the railway as a political weapon when the loss on the other side (i.e., ROK) is larger than themselves (DPRK). One possible measure is to pay a certain levy for the railway usage, and another is to promote economic activities dependent to rail operation (i.e., trade facilitation and job creation around the railway). The higher the economic dependency on the railway, the less likely for TKR to become a political weapon: the decision to close the Gaesung Industrial Complex was by ROK not DPRK whose economic gain was larger. In parallel, the mode share for intraregional trade in Eurasia should be maintained at the balanced manner to 1) guarantee a comprehensive development of regional logistics system for rail, road and seaway and 2) make railway a less attractive political weapon. Although the paper elaborated on the harms of road-seaway freight transport, the shares of these two modes increased exponentially for their merits (i.e., door-to-door delivery and bulk management). Hence, the argument for TKR connection should be understood as a complementary mode to balance mode sharing for balanced low carbon development rather than a substitute of current logistics system. Furthermore, the expected loss from railway disconnection dramatically reduces with availability of competitive alternative trade routes that merit as the political weapon diminishes.

It is important to understand that current road/seaway centered freight movement between ROK and Eurasia is not a sustainable way of business as it poses great risks to global climate change as much as it is to regional air quality, public health and local quality of life (accidents and economic opportunity). On the contrast to the externalities of the current road-centered domestic freight movement, there are many socioeconomic gains expected from TKR connection to trans-continental railways. It clearly adds sustainability to the logistics network of ROK. A simplified calculation to gauge how much emission can be reduced through domestic rail facilitation with TKR may assume: a full mode shift on the intermodal transit freight goods produced in Seoul, Kkyonoggi region and shipped at the Port of Busan either for the final consumption in China or the rail shift at Ports of Liayungang, Shanghai and Qingdao. Under these assumptions, the emission reduction of approximately $25 \%$ of the total PM10 emission recorded from the road freight activity in 2014. The amount is equivalent to $15 \%$ of the total road emission and $2 \%$ of the total national emission. The reduction of ROK-China shuttle shipping may, in turn, relieve the exacerbating environmental conditions in the Yellow Sea, which UNDP/GEF reported as one of the most polluted regional seas in the world [28].

Author Contributions: Conceptualization, M.L. and S.-Y.C.; formal analysis, M.L.; investigation, M.L.; writing-original draft preparation, M.L.; writing—review and editing, M.L.; supervision, S.-Y.C.; funding, M.L. and S.-Y.C. All authors have read and agreed to the published version of the manuscript.

Funding: This research received no external funding.

Conflicts of Interest: The authors declare no conflict of interest.

\section{References}

1. KOTI. An Analysis on the Logistics Condition and Freight Demand of International Corridors in Eurasia II; KOTI Research Basic-RR-17-10; KOTI: Kkyonggi-do, Korea, 2017.

2. IEA Statistics Homepage. Available online: https://www.iea.org/subscribe-to-data-services/co2-emissionsstatistics (accessed on 5 September 2020). 
3. Harrison, R.M.; Yin, J. Particulate matter in the atmosphere: Which particle properties are important for its effects on health. Sci. Total Environ. 2000, 249, 85-101. [CrossRef]

4. Zhang, Q.; Jiang, X.; Tong, D.; Davis, S.J.; Zhao, H.; Geng, G. Transboundary health impacts of transported global air pollution and international trade. Nature 2017, 543, 705-709. [CrossRef]

5. IEA; UIC. Railway Handbook 2016: Energy Consumption and $\mathrm{CO}_{2}$ Emissions; IEA: Paris, France, 2015.

6. United Nations. Mobilizing Sustainable Transport for Development; UN: New York, NY, USA, 2016.

7. IEA. The Future of Rail: Opportunities for Energy and the Environment; IEA: Paris, France, 2019.

8. Janic, M.; Vleugel, J. Estimating potential reductions in externalities from rail-road substitution in Trans-European freight transport corridors. Transp. Res. Part D Transp. Environ. 2012, 17, 154-160. [CrossRef]

9. Lee, B.S. “Towards East Asia Rail Community," Yonhap News Report on 26 December 2018. Available online: https://www.yna.co.kr/view/AKR20181226043700504 (accessed on 8 August 2020).

10. KMI. Logistics Cooperation in Northeast Asia: Mutual prosperity-Focusing on TKR. In Proceedings of the Busan International Port Conference, Busan, Korea, 2 November 2018.

11. Seo, C.H. "Symbiotic Relationship Building in East Asia through TKR," Greenpost Korea Report on 26 June 2019. Available online: http://www.greenpostkorea.co.kr/news/articleView.html?idxno=105994 (accessed on 10 August 2020).

12. KIIF; KEEI; KEI; KOTI. Report on the Transport Energy Re-Pricing Policy Joint Research; KIIF: Seoul, Korea, 2017.

13. Nealer, R.; Matthews, H.S.; Hendrickson, C. Assessing the energy and greenhouse gas emissions mitigation effectiveness of potential US modal freight policies. Transp. Res. Part A Policy Pr. 2012, 46, 588-601. [CrossRef]

14. Panagakos, G.; Psaraftis, H.N. Model-based corridor performance analysis-An application to a European case. Eur. J. Transp. Infrastruct. Res. 2017, 17, 225-247.

15. Chapman, L. Transport and climate change: A review. J. Transp. Geogr. 2007, 15, 354-367. [CrossRef]

16. Bhattacharyay, B.N. Seamless sustainable transport connectivity in Asia and the Pacific: Prospects and challenges. Int. Econ. Econ. Policy 2012, 9, 147-189. [CrossRef]

17. Mostert, M.; Caris, A.; Limbourg, S. Road and intermodal transport performance: The impact of operational costs and air pollution external costs. Res. Transp. Bus. Manag. 2017, 23, 75-85. [CrossRef]

18. Colvile, R.N.; Hutchinson, E.J.; Mindell, J.S.; Warren, R.F. Transport sector as a source of air pollution. Atmos. Environ. 2001, 35, 1537-1565. [CrossRef]

19. Weisbrod, G.; Vary, D.; Treyz, G. Measuring economic costs of urban traffic congestion to business. Transp. Res. Rec. J. Transp. Res. Board 2003, 1839, 98-106. [CrossRef]

20. Lim, H.B. A political economy of trans-Korea railway and trans-continental railway. J. Korean Reg. Dev. Assoc. 2018, 31, 251-270.

21. KOTI. Cooperation Tasks on Trans-Korean Railway. KOTI Special Edition. In Monthly KOTI Magazine on Transport; KOTI: Seoul, Korea, 2018; Volume 244.

22. Yoon, J. Politics of the TKR-TSR linkage: Challenges and international cooperation. J. Int. Relat. 2019, 22, 83-104. [CrossRef]

23. KOTI. Analysis on the South-North Overland Transport Demand and Costs; KOTI: Sejong, Korea, 2005.

24. KMI. Logistics cooperation in Northeast Asia: Mutual prosperity-Focusing on TKR. In Proceedings of the Busan International Port Conference, Busan, Korea, 2 November 2020.

25. KMI. KMI Trend Analysis; KMI Weekly Report; KMI: Busan, Korea, 2019; Volume 140.

26. MOLIT Statistics Homepage. Available online: http://stat.molit.go.kr (accessed on 10 September 2020).

27. MOLIT. Logistics Policybook 2018; MOLIT: Seoul, Korea, 2018.

28. MOLIT. Statistical Yearbook of MOLIT 2018; MOLIT: Seoul, Korea, 2019.

29. Busan Development Institute. Port E Airport Logistics Statistics 2018; BDI: Busan, Korea, 2018.

30. Port of Busan Statistics Homepage. Available online: https://new.portmis.go.kr/ (accessed on 1 August 2020).

31. Incheon International Airport Homepage. Available online: https:/www.airport.kr/co/ko/cpr/ statisticOfLocalAirport.do (accessed on 1 August 2020).

32. Korea Shipping Gazette Homepage. Available online: http://www.ksg.co.kr/ (accessed on 1 August 2020).

33. Song, J.Y.; Na, H.S. A Study on the intercontinental transportation competitiveness enhancement plan between Northeast Asia and Europe using the Trans-Siberian Railway. IACSIT Int. J. Eng. Technol. 2012, 4, 208-212. [CrossRef] 
34. Kim, Y.J.; Park, J.; Oh, Y.H. Comparative analysis on the rail and road freight transportation: Air contaminant and greenhouse gas emission. J. Korean Acad. Ind. Coop. Soc. 2016, 17, 94-101.

35. PM Statistics Homepage Managed by Ministry of Environment. Available online: http://www.me.go.kr/ cleanair/sub02.do (accessed on 25 July 2020).

36. UNDP/GEF YSLME Project. The Yellow Sea: Analysis of Environmental Status and Trends; Regional Synthesis Reports; UNDP/GEF: Incheon, Korea, 2007; Volume 3.

37. Erina. A Competitive Environment for Linking TSR E TKR; ERINA: Tokyo, Japan, 2018.

38. Korean Expressway Corporation Statistics Homepage. Available online: https://www.ex.co.kr/site/com/ pageProcess.do (accessed on 15 August 2020).

39. Korea National Statistics Portal Homepage. Available online: http://www.index.go.kr/potal/main/ EachDtlPageDetail.do?idx_cd=1248 (accessed on 13 November 2020).

40. KOROAD. Comparison between OECD Members on Road Accidents; KOROAD: Seoul, Korea, 2019.

41. Bryan, J.; Weisbrod, G.E.; Martland, C.D. Rail Freight Solutions to Roadway Congestion: Final Report and Guidebook; National Cooperative Highway Research Program Report 586; Transportation Research Board: Washington, DC, USA, 2007.

42. KOTI. Korean National Logistics Costs in 2016; KOTI: Sejong, Korea, 2019.

43. Korea CDC Portal Homepage. Available online: http://www.cdc.go.kr/npt/biz/npp/nppMain.do (accessed on 16 August 2020).

44. Cheon, J.; Yang, Y.J.; Yoon, Y.S.; Lee, E.S.; Lee, J.H.; Huh, Y.; Mun, J.W.; Jhung, C.H.; Hyun, B.R. Influence of Fine Particulate Dust Particulate Matter on Respiratory Virus Infection in the Republic of Korea. Korea J. Fam. Pr. 2019, 9, 454-459. [CrossRef]

45. KMI. A Study on Integration of Logistics Systems between South and North Korea (III); KMI: Seoul, Korea, 2009.

46. Oh, K.Y.; Lee, J.E. A study on the barriers and development strategic for TKR using in-depth interview method. Korea Logist. Rev. 2018, 28, 99-109.

Publisher's Note: MDPI stays neutral with regard to jurisdictional claims in published maps and institutional affiliations.

(C) 2020 by the authors. Licensee MDPI, Basel, Switzerland. This article is an open access article distributed under the terms and conditions of the Creative Commons Attribution (CC BY) license (http://creativecommons.org/licenses/by/4.0/). 